\title{
BM] Global Heatth Fifth anniversary of the Sex And Gender Equity in Research (SAGER) guidelines: taking stock and looking ahead
}

\author{
Sanne A E Peters, ${ }^{1,2,3}$ Thomas F Babor, ${ }^{4}$ Robyn N Norton, ${ }^{1,3}$ Janine A Clayton, ${ }^{5}$ \\ Pavel V Ovseiko (D) , ${ }^{6}$ Cara Tannenbaum, ${ }^{7}$ Shirin Heidari ${ }^{8,9}$
}

To cite: Peters SAE, Babor TF, Norton RN, et al. Fifth anniversary of the Sex And Gender Equity in Research (SAGER) guidelines: taking stock and looking ahead. BMJ Global Health 2021;6:e007853. doi:10.1136/ bmjgh-2021-007853

Received 1 November 2021 Accepted 8 November 2021

Check for updates

(c) Author(s) (or their employer(s)) 2021. Re-use permitted under CC BY-NC. No commercial re-use. See rights and permissions. Published by BMJ.

For numbered affiliations see end of article.

Correspondence to Dr Sanne A E Peters; speters@georgeinstitute.org.uk
This year marks the fifth anniversary of the publication of the Sex And Gender Equity in Research (SAGER) guidelines, ${ }^{1}$ which provide recommendations to authors, journal editors, peer-reviewers and publishers for ensuring that sex and gender considerations are appropriately reported in the scholarly literature. The guidelines were developed in recognition of the persistent sex and gender gaps in research across disciplines, especially in health and biomedical research. At the time of development, there was notable resistance to implement sex and gender policies, reflecting a lack of awareness of the importance of sex and gender as critical determinants of health and well-being. ${ }^{2}$

The guidelines have now been translated into six languages, adopted by a growing number of journals, encouraged by major publishers, and extensively used by researchers. ${ }^{3}$ Despite these successes and growing awareness, there remain critical barriers to systematic implementation of sexbased and gender-based analyses in research and reporting. For example, many COVID-19 trials continue to include fewer women than men, ${ }^{4}$ and there is a persistent lack of sexbased and gender-based analyses in several medical disciplines, ${ }^{56}$ often without justification. Here, we reflect on the barriers to the uptake and implementation of the SAGER guidelines and offer recommendations to overcome them.

\section{CONCERNS ABOUT MANDATING}

There are concerns about the additional time and costs associated with the larger sample sizes or different statistical analyses required for sex-based and gender-based analyses. However, several national funding agencies have made these analyses a funding requirement, with success, ${ }^{7}$ and budgets are available to factor in additional costs. Furthermore, there is value in presenting data by sex or gender to indicate trends and enable future meta-analyses.

There are also concerns about the burden on reviewers imposed by enforcing the SAGER guidelines. Although checking for sex and gender reporting does take time, the perceived burden on reviewers can be minimised if submitted manuscripts are screened prior to peer-review. Screening manuscripts for adherence to editorial policies is already common practice in most journals.

\section{LACK OF TIME, CAPACITY AND RESOURCES}

Journal editors may lack the time, capacity and resources to introduce the SAGER guidelines as a formal policy or to enforce adherence. Journals with relatively few issues per year may find it particularly challenging considering infrequent board meetings and competing priorities. Nevertheless, journals should consider implementation of the SAGER guidelines, as with other mandatory reporting guidelines, as way to improve scientific quality. Support from publishers could facilitate introduction of the SAGER guidelines across all journals. ${ }^{8}$

\section{RESISTANCE OR LACK OF AWARENESS}

Some journals are resistant to include the SAGER guidelines or consider them not applicable to their field. Journals may choose to implement more tailored policies by adapting SAGER to specific disciplines. Some editors have expressed a lack of knowledge of sex and gender (and their differences) among reviewers. Online trainings, such as 
those developed by the Canadian Institutes of Health Research, ${ }^{9}$ could be offered to reviewers to improve their knowledge about integrating sex and gender in health research. Editors may also benefit from diversity training, as implicit bias is often a persistent problem in the remediation of sex and gender disparities. ${ }^{10}$

\section{TECHNICAL CHALLENGES}

Individual journals might not be able to change the instructions to authors (ITA) or electronic submission systems to align with the SAGER guidelines. Large publishers often have standard ITA for all journals and rarely offer flexibility to modify the ITA. Pressure from journal editors can encourage publishers to incorporate the SAGER guidelines alongside other reporting guidelines across all journals. Moreover, submission systems can be tailored to incorporate a tick box for authors to claim adherence and add questions to the evaluation form for peer-reviewers.

\section{LOOKING AHEAD}

The SAGER guidelines offer an opportunity to improve research and reporting practices. While they have stimulated discussion and have been incorporated into the ITA of an increasing number of journals, more needs to be done to ensure wider uptake and implementation. Efforts to embed relevant intersectional dimensions, such as age, race, ethnicity, social identity and geographical diversity into research and reporting practices should also continue intersection with sex and gender to influence on health and societal outcomes can be addressed appropriately. Although the implementation of the SAGER guidelines by journal editors is an important step, this should not be the responsibility of researchers and journal editors alone. If we are to improve research for the benefit of everyone, structural and systemic changes across the entire research and innovation cycle are required, involving engagement with universities, professional societies, ethics committees, funders, industry and policy-makers.

\footnotetext{
Author affiliations

${ }^{1}$ The George Institute for Global Health, Imperial College London, London, UK

${ }^{2}$ Julius Center for Health Sciences and Primary Care, University Medical Center Utrecht, Utrecht, The Netherlands

${ }^{3}$ The George Institute for Global Health, University of New South Wales, Sydney, New South Wales, Australia

${ }^{4}$ Department of Public Health Sciences, University of Connecticut School of Medicine, Farmington, Connecticut, USA

${ }^{5}$ Office of Research on Women's Health, National Institutes of Health, Bethesda, Maryland, USA
}

${ }^{6}$ Radcliffe Department of Medicine, University of Oxford, Oxford, UK ${ }^{7}$ Canadian Institutes of Health Research, Institute of Gender and Health, Universite de Montreal, Montreal, Quebec, Canada

${ }^{8}$ GENDRO, Geneva, Switzerland

${ }^{9}$ Global Health Center, Graduate Institute of International and Development Studies, Geneva, Switzerland

Twitter Sanne A E Peters @saepeters

Contributors SP wrote the first draft. All authors provided intellectual input and approved the final manuscript.

Funding SP is supported by a UK Medical Research Council Skills Development Fellowship (MR/P014550/1).

Competing interests None declared.

Patient consent for publication Not applicable.

Ethics approval This study did not receive nor require ethics approval, as it does not involve human and animal participants.

Provenance and peer review Not commissioned; internally peer reviewed.

Data availability statement № data are available.

Open access This is an open access article distributed in accordance with the Creative Commons Attribution Non Commercial (CC BY-NC 4.0) license, which permits others to distribute, remix, adapt, build upon this work non-commercially, and license their derivative works on different terms, provided the original work is properly cited, appropriate credit is given, any changes made indicated, and the use is non-commercial. See: http://creativecommons.org/licenses/by-nc/4.0/.

ORCID iD

Pavel V Ovseiko http://orcid.org/0000-0002-3504-2177

\section{REFERENCES}

1 Heidari S, Babor TF, De Castro P, et al. Sex and gender equity in research: rationale for the SAGER guidelines and recommended use. Res Integr Peer Rev 2016;1:2.

2 Mauvais-Jarvis F, Bairey Merz N, Barnes PJ, et al. Sex and gender: modifiers of health, disease, and medicine. Lancet 2020;396:565-82.

3 The European Association of Science Editors. The SAGER guidelines. Available: https://ease.org.uk/communities/genderpolicy-committee/the-sager-guidelines/ [Accessed 09 Sep 2021].

4 Palmer-Ross A, Ovseiko PV, Heidari S. Inadequate reporting of COVID-19 clinical studies: a renewed rationale for the sex and gender equity in research (SAGER) guidelines. BMJ Glob Health 2021;6:e004997.

5 Scott PE, Unger EF, Jenkins MR, et al. Participation of Women in Clinical Trials Supporting FDA Approval of Cardiovascular Drugs. $J$ Am Coll Cardiol 2018;71:1960-9.

6 Carcel C, Woodward M, Balicki G, et al. Trends in recruitment of women and reporting of sex differences in large-scale published randomized controlled trials in stroke. Int J Stroke 2019;14:931-8.

7 Haverfield J, Tannenbaum C. A 10-year longitudinal evaluation of science policy interventions to promote sex and gender in health research. Health Res Policy Syst 2021;19:94.

8 Elsevier Connect. The importance of sex and gender reporting: In support of the SAGER guidelines. Available: https://www.elsevier. com/connect/editors-update/the-importance-of-sex-and-genderreporting [Accessed 08 Oct 2021].

9 Canadian Institutes of Health Research \& Health. Sex and gender training modules. Available: http://www.cihr-irsc-igh-isfh.ca/ [Accessed 07 Sep 2021].

10 FitzGerald C, Hurst S. Implicit bias in healthcare professionals: a systematic review. BMC Med Ethics 2017;18:19. 